\title{
Economic Aspects of Women's Empowerment Program in Central Sulawesi, Indonesia
}

\author{
Nuraisyah Ambo ${ }^{1}$ \\ Email: nurasyiahambountad@gmail.com \\ ${ }^{1}$ Sociology Study Program, Faculty of Social and Political Sciences, Tadulako University, \\ Palu, Central Sulawesi, Indonesia
}

\begin{abstract}
The goal of this research is to see how successful the Women's Empowerment Program is at improving the economy in Poso Regency. With the aim of answering research questions, such as how to motivate women in improving the economy in Poso district, the research approach used qualitative research and data processing with descriptive analysis methods. Data was gathered through library analysis and recording, observation, and in-depth interviews with a variety of informants, including Poso, Observers of Women, Women's Organizations, and three Home Industry Entrepreneurs from the Office of Women's Empowerment and Child Protection (DP3A) district. According to the findings of this report, the Women's Empowerment Program at DP3A Poso Regency is not succeeding. Since the program being introduced is not on track, implementation times are often late, there is a lack of executive engagement, there is no bureaucratic structure or standard operating procedure, and there are insufficient human resources. There is also a lack of communication both internally (inter-coordination) and externally (external coordination).
\end{abstract}

Keywords: Economy, Empowerment, Indonesia \& Women Empowerment

Received: March 3, 2021

Revised: March 29, 2021

Accepted: April 19, 2021

\section{Introduction}

Women's empowerment has become one of the world's top priorities for long-term growth. Also in developing nations, this aspect is taken into consideration, since women in developed countries face a variety of forms of discrimination in various ways. Gender inequality has been identified as one of the most important barriers to development in many countries. Empowerment of women (Okonofua \& Omonkhua, 2021). The expansion of women's assets and their ability to participate, take on strategic roles, negotiate, control, and hold accountable institutions that affect their lives is alluded to as women's empowerment (Mohapatra \& Sahoo, 2016).

Women's empowerment includes a woman's understanding of her rights, self-confidence, the ability to control her life both at home and outside the home, and the power to impact social change (Sohail, 2014). Economic, social, political, and personal empowerment are all intertwined and dependent on each other. Women's economic empowerment entails granting them economic privileges (Al-Shami et al., 2017). Women's position in society must be equal to that of humans by the elimination of inequality and injustice. Women must be treated with respect in society. Political empowerment effectively gives women seats in provincial and national legislature, as well as one vote per woman. Personal empowerment refers to a woman's right to privacy in her personal life (Cornwall., 2016).

Women's health is an obvious manifestation of their empowerment. Absolute well-being is defined as the process of enhancing women's performance as measured by measures such as 
educational attainment, health and nutrition, labor participation, mobility, and asset ownership (Mehra, 1997). Relative welfare, on the other hand, is the mechanism of elevating women's status in the household in relation to men, as shown by women's participation in household processes such as decision-making and control over household income (Alkire et al., 2013).

Various groups, both at the national and international levels, have long been concerned about empowering women through economic development. After being discussed at the Cairo Population Conference, this topic has become increasingly relevant (ICPD 1994) (Onditi 2017). The struggle for human rights, as enshrined in the 1948 United Nations Declaration of Human Rights, cannot be removed from the issue of justice and gender equality (HAM). (Akhter, 2020).

The Convention on the Elimination of Discrimination Against Women (CEDAW), which was ratified by Law No. 7 of 1984, is a treaty that prohibits discrimination against women (Leone., 2006). Requiring the state and government to protect all citizens from discriminatory practices and to demonstrate a strong commitment to improving the quality of life and achieving justice for all Indonesian.

The Indonesian government is striving to improve women's services. According to Presidential Instruction Number 9 of 2000 on gender equality, every person, including women, is obliged to provide security and improve the quality of life by empowering women. A women's rights approach and strategy must be implemented by all ministries, municipal governments, and government departments, as well as all state administering entities, both central and local. (gender mainstreaming) Women and men's interests are taken into account and cared for as strategies are planned, determined, and enforced (responsive gender) (Robani \& Ekawaty, 2019).

The Indonesian women's movement offered a new debate and during reform period that blurred the lines between private and public life. This discourse is reflected in pro-women legislation such as the 2004 Domestic Violence Elimination Act. The Indonesian women's movement has also included women's political empowerment in its agenda. Since 2002, the Election Law and Political Party Law have also included a 30 percent quota policy for women's representation. A number of pro-women laws have been enacted at the policy level, but their enforcement is still incomplete and there are numerous records (Lockley et al., 2019).

The government issued a Women Empowerment Development Policy, which is outlined in the 2019-2024 National Medium Long Term Development Plan, to improve the situation of women in order to achieve equality and justice in all facets of life. (RPJPMN 2019-2024) and set forth in the Strategic Plan of the Ministry of Women's Empowerment and legalized in the Decree of the State Minister for Women's Empowerment Number 27/Kep/Men/IV/2005. The purpose of the Women's Empowerment Development Policy is to improve the quality of life and protection of women, through improving the status, position and condition of women in development and governance through strengthening female human resources. (Samarakoon \& Parinduri, 2015).

Local government is the implementor of women's empowerment in the region. This is in accordance with the duties and authorities of the Regional Government which are attached to the duties and authorities of Regional Heads and Deputy Regional Heads as stipulated in Article 26 of Law Number 32 Year 2004 concerning regional autonomy (Mufti et al., 2020). In a formal legal sense, the local government has the duty, jurisdiction, and obligation to implement women's empowerment through sustainable economy. Local governments' position in women's empowerment involves, at a minimum, improving women's quality of life and protecting them, with a strategy of considering women's experiences, desires, needs, and 
problems in the preparation, implementation, monitoring, and evaluation of all policies and programs in various fields of life and growth (Hasbullah et al., 2021).

Empowering women is critical to the family's survival, both in terms of spiritual fostering for children and meeting the family's economic needs as one of the key pillars of family life. (Robani \& Ekawaty, 2019). It shows that many women are actively interested in helping to support the family economy in this way. The rise of female entrepreneurs in rural areas is one of them. From a gender perspective, this means that men and women in rural areas have equal access to entrepreneurship opportunities.

Women have limitations in carrying out their activities in terms of improving their economy, especially in rural areas, such as low education, skills and job opportunities, as well as women's ideological barriers related to households. In addition, women face a set of challenges known as the "triple burden of women," which requires them to perform reproductive, development, and social roles in society at the same time (Gallaway \& Bernasek, 2004).

The government has directed women's participation in the workforce, recognizing the value of their ability. Three roles of women can be seen in relation to the attempt to determine the contribution or position of women (Tjiptaningsih, 2018), that is; (1) The constructive role entails tasks that directly contribute to the family's financial well- being. Farmers and ranchers, for example, work for a living whether they are paid or not. (2) Giving birth, breastfeeding, caring for and caring for children, fetching water, cooking, cleaning houses, and sewing are all productive roles that contribute to human and family survival. (3) Activities that are not limited to family arrangements but also in the community, such as positions in cooperatives, farmer associations, and so forth, are examples of social roles.

\section{Methods}

The aim of this study is to examine the role of women in improving the family economy in Poso Regency, Central Sulawesi, Indonesia. This study is motivated by the fact that Poso Regency differs significantly from other areas in Central Sulawesi Province. The researcher used observations along with in-depth interviews to gather evidence for this report, as well as providing field notes about incidents he observed in the field. In order to meet the study goals, the Purposive approach was used to select informants. The informants were divided into groups of up to seven individuals, depending on their ability to provide the necessary data and facts. The information and data gathered were then processed using the triangulation method, which involves cross-checking the multiple informants. Conclusions regarding the method of implementing women's liberation can be made using this triangulation approach. This is a qualitative study of the results.

\section{Results and Discussion}

As the person in charge of the Women's Empowerment initiative for economic access, the Office of Women's Empowerment and Child Protection (DP3A) This discussion would explain the execution of the Women's Empowerment program in Poso Regency, based on the outcomes of interviews and consultations, as well as findings and paper analyses, in conjunction with the Poister definition, which is a tool. The following is an example of a surgical material study problem.

\section{Output}

The Poso District Women Empowerment and Child Protection Agency (DP3A) is in charge of formulating technical policies, compiling work plans, implementing or organizing family empowerment, conducting technical assistance in the implementation of women's empowerment, monitoring and evaluating the implementation of women's empowerment, thus 
it can be concluded that the DP3A of Poso district is Regional Work Units (SKPD) that are technically responsible for women's empowerment programs.

The policies set by DP3A Poso district for women's empowerment programs in women's economic access are in 2019, namely: preparation of a protection system for women, advocacy for domestic violence, fostering home industry, functional literacy, basic leadership training, training services at the Integrated Service Center for Women's Empowerment and Children (P2TP2A) in Poso district, counseling for housewives in building a prosperous family and socialization of gender literate sub-districts, nine priority programs, increasing women's empowerment in women's economic access in 2019, with a targeted cost of Rp. 625.103.400, realization Rp. Rp 575. 093.408.

Of the 9 activities that were targeted to be implemented, there were 5 activities (44.4\%) that were late to be implemented, namely: (1) Functional literacy, (2) Fostering Home Industry, (3) Training for Integrated Service Center for Women and Children Empowerment (P2TP2A). (4) Advocacy for Domestic Violence, the reason for the drafting was late, the first was because the funds were disbursed late the funds that have been determined are insufficient for its allocation, as a result, apart from being late, the benefits are less felt by the beneficiaries, in this case women who are the target of the program, because these activities are ultimately implemented only to meet project needs (administrative responsibility).

However, based on the document study, there are activities that are carried out on time, such as: (1) Outreach for the Literacy District, (2) Women's Leadership Training for women's organizations in the Poso Kota sub- district, and (3) Counseling for housewives in building a prosperous family. There were 2 activities $(22.3 \%)$ which were carried out incompletely, due to the efficiency of funds, namely: (4) Establishment of Kopersai, (5) Entrepreneurship Training (P3A Office of Poso Regency, Renstra and Lakip 2019).

The basic substance of the implementation of 9 activities in the Women's Empowerment program, namely: (1) Functional Literacy, aims to introduce women to reading and writing, in addition to providing basic skills, such as weaving bags, ropes and hats and ropes, as well as the skills chosen in accordance with needs learning objectives. The citizens learning for functional literacy are selected from community representatives from 4 sub-districts in Poso Regency including the Research Location District, who do not know how to read and write, with ages over 18 years, with a total of 30 people.

The resource persons for this activity were the functional literacy facilitators of the Poso District Education and Training Center, this activity lasted for one month. According to the informant, this activity had not been going well, because the final output of this activity was that participants were able to recognize letters and be able to write and read and master the skills given by resource persons, but until the end of the activity there are still learning participants who have not been able to read and write, they are more interested in providing skills, because they think that the skills provided can bring in money to provide additional household income.

Home Industry Development Activities. This activity is intended to further introduce home industry players, such as craftsmen in the small industry skills industry, and market snacks business actors, the training materials provided are knowledge about quality raw materials, how to access raw materials, production methods, production design and marketing management, activities. This was attended by 30 home industry players (15 Roa Fish industry players and 15 market snack food business players) from representatives of 4 Districts in Poso Regency. This activity was carried out for 2 days. The concept of activities is carried out in an integrated and sustainable manner, in accordance with the objectives of this activity. What is 
meant here is that after training on production management and marketing management, the assisted group is provided with assistance in developing their business, such as providing assistance in accessing business capital and marketing of products. However, the fact is in the field based on information from informants, saying we were only given production and marketing management materials, for 2 days on the schedule for the 4-day activity, that's not all that was disappointing, after the training activities, they were immediately left without any ongoing assistance and guidance for business development. done alone, without assistance from the P3A Office of Poso Regency. (Results of Interview with Informants, 18 February 2020).

This explanation indicates that the P3A Office of Poso Regency, especially in fostering home industry, has not been running well because the objectives of sustainable and sustainable coaching activities are not implemented, even after training business actors are left without providing assistance, even having never visited business premises, let alone development funds or facilitation for access to business capital as promised during the training. All that was forgotten and never touched by the P3A district Poso office, as promised during the training.

According to an informant in the field of empowerment, that: problems in the implementation of women's empowerment programs in women's economic access at the P3A Office of Poso Regency, the first is the factor of limited staff in the P3A sector, only 11 people, then on average only high school education, besides that there is a transfer policy, where there is frequent shift in employees, where employees who come do not understand the program, so it is very difficult to implement it, start anew, while those who are just starting to work and learn to understand their main duties, suddenly there is another shift, this is what confuses me as the head of the department P3A Kabupaten Poso and that is one of the reasons that my staff cannot work professionally because they are often replaced

This opinion provides an understanding that the purpose of the women's empowerment program in women's economic access is to increase access and control in economic access and the benefits for women's independence cannot be realized, because what is a problem in implementing women's empowerment programs in women's economic access at the P3A office in Poso district, the first is the limited staff factor in the PP sector, only 11 people, then the average program implementer only has high school education, besides that there is a transfer policy, where employee shifts often occur, where employees who come do not understand gender responsive programs, so that It is very difficult to implement programs that are not understood as a result of these employees learning again from the beginning, as a resul program implementation can be hampered.

\section{Service Quality}

Based on the facts of research, women feel that the services provided by P3A in Poso Regency, especially for the Women's Economic Improvement program, show dissatisfaction (75\%), this data gives an understanding that in fact the P3A of Poso Regency in implementing the Pe Perempuan Economic Improvement program has not been carried out properly, accessibility, comfort, politeness, and safety and from the side of time has not been done well (Thuy \& Trinh, 2020).

\section{Effectiveness}

One of the strategic steps taken by the central government in the empowerment program for the women's economy, the central government through the Ministry of Women's Empowerment has issued a regulation of the State Minister for Women's concerning Guidelines for Implementing the Improvement of the Quality of Women's Life. Through the improvement of the women's economy, this regulation was made by considering the implementation of the 
provisions of Government Regulation concerning the Division of Government Affairs between the government, Provincial Government and Regency / City Government, it is necessary to stipulate a Regulation of the State Minister for Women's Empowerment of the Republic of Indonesia concerning Guidelines for the Implementation of Empowerment. Female.

The aforementioned guidelines are the basis for the implementation of the quality of life and women's programs. starting from the provincial to Regency / City levels. Furthermore, in a Ministerial Regulation, the objectives of the Women's Empowerment Program as stated in article 3 have been stated and explained as follows: Guidelines for the implementation of Women's Empowerment, aiming at Ensuring the implementation of the Women's Empowerment Program in a systematic, comprehensive, sustainable and integrated manner, but based on research on this matter. Maximum activities have not been implemented, where each agency runs its own Empowerment Program.

\section{Cost-Effectiveness}

There is a separate calculation carried out by the Poso Regency DPRD in determining the budget for the implementation of women's empowerment. The P3A Office of Poso Regency cannot reject the budget that has been realized, even though the realization is not in accordance with the budget proposal, but because this is a policy, for the implementation of activities, the P3A of Poso Regency just needs to adjust, even though the realization costs are very limited. Activities will continue to be carried out, by conditioning the existing budget, without reducing the substance of the activity objectives.

Research facts show most of them $(78,57 \%)$ The informant argued that the cost effectiveness of implementing the Women Empowerment program with the Improvement of the Women's Economy in 2019 in Poso Regency has not been effective, even though the funds for the quality of life program for women have increased from year to year. The 2018 activity budget gets a budget Rp.1.600.743.075, in 2019 it has increased to reach numbers Rp. 2.187.617. 146, means that there is an increase in funds of around $35.5 \%$. For the program for the quality of life / women's economic improvement, there was also an increase from 159,020,500 to Rp. 575. 093,408 (26.28\%), by programming 9 activities. (LakipDinas P3A Kab. Poso, 2020).

\section{Customer Satisfaction}

It can be said that the women's empowerment program by P3A in Poso district has not provided satisfaction to the community, because many programmed women's economic improvement activities are not implemented, only because of a lack of funds, actually this does not need to happen, if among the 3 fields in P3A Poso district do internal coordination regarding program funding so as not to overlap.

In line with observations in the field, where there is a lack of participation of women in the Women's Empowerment Program because the program is not based on the needs of women, the formulator does not involve the community / women as program targets, but tends to copy paste from year to year, so that its implementation does not give satisfaction at all. Community, especially if it is accompanied by a lack of planning in the use of time and inadequate other supporting facilities, as a result, let alone not being glanced at, let alone participating in the program.

\section{Conclusion}

The Poso district women's empowerment and child security office's women's empowerment initiative for developing the women's economy has not been going well. The required funds are inadequate to execute the initiative and it is not being applied on time. The bureaucracy's 
finances, temperament, and organization are not yet adequate, and there is a lack of cooperation, both internal and external, between fields in the DP3A Poso district.

\section{References}

Akhter, J., \& Cheng, K. (2020). Sustainable empowerment initiatives among rural women through microcredit borrowings in Bangladesh. Sustainability, 12(6), 2275.

Alkire, S., Meinzen-Dick, R., Peterman, A., Quisumbing, A., Seymour, G., \& Vaz, A. (2013). The women's empowerment in agriculture index. World development, 52, 71-91.

Al-Shami, S. S. A., Majid, I., Mohamad, M. R., \& Rashid, N. (2017). Household welfare and women empowerment through microcredit financing: Evidence from Malaysia microcredit. Journal of Human Behavior in the Social Environment, 27(8), 894-910.

Cornwall, A. (2016). Women's empowerment: What works?. Journal of International Development, 28(3), 342-359.

Gallaway, J. H., \& Bernasek, A. (2004). Literacy and women's empowerment in Indonesia: implications for policy. Journal of economic issues, 38(2), 519-525.

Hasbullah, M. A. S., Ali, M. N., \& Maddukelleng, M. K. (2021). Indonesian Disaster Governance: Public Policy and Social Economic Impact. Elementary Education Online, 20(5), 73-88.

Leone, Sierra. (2006) "Consideration of Reports Submitted by States Parties under Article 18 of the Convention on the Elimination of All Forms of Discrimination against Women." 83. Available from: https://digitallibrary.un.org/record/596133?ln=ru

Lockley, A., Marcoes, L., Nugroho, K., \& Boang-Manalu, A. G. (2019). Women's Collective Action for Empowerment in Indonesia. Jurnal Perempuan, 24(1), 13-26.

Mehra, R. (1997). Women, empowerment, and economic development. The Annals of the American Academy of Political and Social Science, 554(1), 136-149.

Mohapatra, S., \& Sahoo, B. K. (2016). Determinants of participation in self-help-groups (SHG) and its impact on women empowerment. Indian Growth and Development Review.

Mufti, M. I., Kurnia, I., Karim, I., \& Samad, M. A. (2020). Evaluation on Community Empowerment Policy after Conflict Resolution (A Study of Sub District Development Program in Poso District). International Journal of Multicultural and Multireligious Understanding, 7(8), 16-25

Okonofua, F., \& Omonkhua, A. (2021). Women empowerment: A new agenda for socioeconomic development in Saudi Arabia. African Journal of Reproductive Health, 25(1), 9-12.

Onditi, F., \& Odera, J. (2017). Gender equality as a means to women empowerment? Consensus, challenges and prospects for post-2015 development agenda in Africa. African Geographical Review, 36(2), 146-167.

Robani, M. M., \& Ekawaty, M. (2019). Analisis Dampak Pemberdayaan Perempuan terhadap Kesejahteraan Keluarga. AL-MUZARA'AH, 7(1), 1-18.

Samarakoon, S., \& Parinduri, R. A. (2015). Does education empower women? Evidence from Indonesia. World Development, 66, 428-442.

Sohail, M. (2014). Women empowerment and economic development-an exploratory study in Pakistan. Journal of Business Studies Quarterly, 5(4), 210. 
Thuy, N., \& Trinh, E. (2020). Human Resource Development: Overview of the Performance Evaluation and Performance Appraisal viewpoints. Journal La Bisecoman, 1(5), 1519

Tjiptaningsih, W. (2018). Pemberdayaan Perempuan dalam Upaya Peningkatan Ekonomi Keluarga (Studi Kasus Pada Kelompok Usaha Perempuan di Desa Sindangkempeng Kecamatan Greged Kabupaten Cirebon). REFORMASI: Jurnal Ilmiah Administrasi, 2(1). 